\title{
EDITORIAL
}

\section{In This Issue: Humans of Primary Care Research}

\author{
William R. Pbillips, MD, MPH, Editor
}

Ann Fam Med 2019;17:2-3. https://doi.org/10.1370/afm.2341.

$\mathrm{F}$ amily physicians are deeply devoted to people and the transitions in their lives. We do our most important work at birth, developmental milestones, partnering and family formation, loss, decline, death, and grief. In this issue of the Annals of Family Medicine, authors remind us that people are behind our research, innovation, and publications.

Kendrick and a UK team reviewed studies on the care of adults with depression and conclude that risk of recurrence may be lessened with slow tapering of antidepressants and cognitive behavioral therapy. ${ }^{1}$ In screening for depression and anxiety disorders in primary care, Graham and team show that a computerized adaptive test performed similarly to clinical interview and paper-and-pencil tests. Such technology might help screen more patients for these important problems and free up time for clinicians to spend more face-to-face time with patients. ${ }^{2}$ Such opportunities invite us to ask: When family physicians work "at the top of their licenses," what is the most valuable use of their precious time with patients?

Studying children with preexisting medical conditions such as chronic respiratory or cardiovascular disease and diabetes, de Hoog and colleagues in the Netherlands demonstrate that repeated influenza immunization has no negative effect on, and may enhance, long-term protection against respiratory infections. ${ }^{3}$ Hay and colleagues in Bristol, UK, followed a community cohort of children and document that respiratory tract infections can last for over 3 weeks before they resolve spontaneously. ${ }^{4}$ In the long tradition of general practice research, both studies provide useful information on the natural history of common illness in the community.

Technology takes its place in the care of patients and the problems they present in primary care. An increasing need to deliver care for chronic migraine sufferers led Busey to learn the use of botulinum toxin and develop systems to move that process into primary care. ${ }^{5}$ He describes the usual growing pains of moving specialist procedures into primary care and demonstrates that family doctors can learn to do what their patients need. Needles don't treat people; people treat people.
Point-of-care ultrasound exams are performed by FPs/GPs for a variety of diagnostic and screening purposes. Andersen's team in Aalborg, Denmark, reviewed published studies to document current training, practice, and clinical use of ultrasound and recommends more study of this increasingly important clinical service in primary care. ${ }^{6}$

Several articles in this issue underscore that clinicians are people, even when corporateers categorize them as interchangeable providers.

Willard-Grace and her team in two San Franciscoarea health care systems report that, although burnout and low engagement affect both primary care clinicians and staff members, it contributes to turnover among clinicians more than staff. ${ }^{7}$ Analyzing a survey of primary care physicians, Pantell and team find that those who feel their clinics are well-prepared to address and manage patients' social needs report higher job satisfaction and feel they deliver higher quality care. ${ }^{8}$

An essay from a member of that team, Laura Gottlieb, warns that the focus on social determinants of health could worsen health and widen inequities if misapplied by big data, big business, and big tech. She notes that current data on effectiveness of interventions to address social needs in clinical settings is limited and that we know even less about their effect on health and health care disparities. ${ }^{9}$

Studying the University of Washington family medicine residency network, Weidner and team find that graduates' scope of practice has declined despite reporting that they feel well-prepared to provide a range of clinical services. This study documents that trend over more than a decade, 1996-2013, and concludes that scope of practice is declining for reasons other than lack of training. ${ }^{10}$

In an essay recounting her personal path from community organizer to family physician, Morris urges us to focus on community, rather than patient, as the agent of change to transform the root causes of the challenges to their health. ${ }^{11}$ Family doctors understand the need to look upstream, to search for resources in their own practice communities. The question is no longer: Does community organization and action improve conditions and improve health? 
That was answered by pioneer medical scientist Rudolph Virchow (1821-1902), the father of cellular pathology, who famously said: "Medicine is a social science and politics is nothing else but medicine on a large scale." ${ }^{\prime \prime 2}$ The question now is: Does the process of community activation-itself_-improve health?

Researchers are people, too, and articles in this issue explore the content, processes, and history of their efforts to address questions of importance to patients and communities.

An international team led by Goodyear-Smith surveyed family medicine researchers around the globe to identify the evidence needs for primary health care in low- and middle-income countries. ${ }^{13}$ The resulting priority list should help make research more relevant, useful, and meaningful to local communities.

A team from Paris's Sorbonne, led by Ibanez, reports a bibliometric study of the growth of research publications in primary care over 40 years and identified the places and factors associated with research productivity. ${ }^{14}$

Ukhanova and colleagues at Oregon Health and Science University share their innovative program to empower clinical research by embedding research fellows in community teaching practices. These academic experts serve to bridge the usual gaps between research and clinical practice, helping turn clinician curiosity and patient need into data and action. ${ }^{15}$

Gotler takes the historian's approach to tracing the unfinished business of research in the development of family medicine. She points to factors that have shaped family medicine enquiry, including practitioners' reliance on information from other specialties, the desire for an independent academic presence, and the nonlaboratory character of our research questions and methods. She emphasizes that a strong culture of generalist knowledge is crucial to assure family medicine's future and to strengthen its ability to improve the health of individuals, families, and communities. ${ }^{16}$

Editors are people, too, and medical journals are human enterprises. John Geyman founded the first academic journal of record for the new specialty of family medicine in 1974 and has edited several leading peerreviewed journals in the specialty. He shares a tribute to Claire Zimmerman, who worked closely with him on these enterprises, as she closes her long career helping shape the publications of countless family medicine researchers. ${ }^{17}$ An interview with Claire paints more detail on that human face. ${ }^{18}$

The founding editor of the Annals of Family Medicine, Kurt Stange, has just passed leadership of the world's highest impact primary care journal on to the editorial team he built over 16 years. Many have been fortunate to work with Kurt and the community of authors, researchers, reviewers, and readers he nurtured. As a search for a new editor continues, our team will strive to reach out with Kurt's human touch of curiosity, connection, and common sense.

To read or post commentaries in response to this article, see it online at http://www.AnnFamMed.org/content/17/1/2.

\section{References}

1. Maund E, Stuart B, Moore M, et al. Managing antidepressant discontinuation: a systematic review. Ann Fam Med. 2019;17:52-60.

2. Graham AK, Minc A, Staab E, Beiser DG, Gibbons RD, Laiteerapong $\mathrm{N}$. Validation of the computerized adaptive test for mental health in primary care. Ann Fam Med. 2019;17:23-30.

3. de Hoog MLA, Venekamp RP, Damoiseaux RAMJ, et al. Impact of repeated influenza immunization on respiratory illness in children with preexisting medical conditions. Ann Fam Med. 2019;17:7-13.

4. Hay AD, Anderson E, Ingle S, Beck C, Hollingworth W. Respiratory tract infections in children in the community: prospective online inception cohort study. Ann Fam Med. 2019;17:14-22.

5. Busey B. Expanding the use of botulinum toxin in primary care for chronic migraine. Ann Fam Med. 2019;17:85.

6. Andersen CA, Holden S, Vela J, Rathleff MS, Jensen MB. Point-ofcare ultrasound in general practice: a systematic review. Ann Fam Med. 2019;17:61-69.

7. Willard-Grace R, Knox M, Huang B, Hammer H, Kivlahan C, Grumbach K. Burnout and health care workforce turnover. Ann Fam Med. 2019;17:36-41.

8. Pantell MS, De Marchis E, Bueno A, Gottlieb LM. Practice capacity to address patients' social needs and physician satisfaction and perceived quality of care. Ann Fam Med. 2019;17:42-45.

9. Gottlieb LM, Alderwick H. Integrating social and medical care: could it worsen health and increase inequity? Ann Fam Med. 2019; 17:77-81.

10. Weidner AKH, Chen FM. Changes in preparation and practice patterns among new family physicians. Ann Fam Med. 2019;17:46-48.

11. Morris JE. When "patient-centered" is not enough: a call for community-centered medicine. Ann Fam Med. 2019;17:82-84.

12. Friedlander E. Rudolf Virchow on pathology education. http://www. pathguy.com/virchow.htm. Accessed Nov 152018.

13. Goodyear-Smith F, Bazemore A, Coffman M, et al. Primary care research priorities in low- and middle-income countries. Ann Fam Med. 2019;17:31-35.

14. Hajjar F, Saint-Lary O, Cadwallader J, et al. Development of primary care research in North America, Europe, and Australia from 1974 to 2017. Ann Fam Med. 2019;17:49-51.

15. Ukhanova M, Heintzman J, Tseng A, Yamashita D, LikumahuwaAckman S, DeVoe J. Partnering research fellows and clinicians in practice settings. Ann Fam Med. 2019;17:86.

16. Gotler RS. Unfinished business: the role of research in family medicine. Ann Fam Med. 2019;17:70-76.

17. Geyman JP. Tribute to Claire Zimmerman. Ann Fam Med. 2019;17:4.

18. Gotler RS. Reflections on 4 decades of family medicine editing. Ann Fam Med. 2019;17:5-6. 